\title{
Hemangioblastoma of the Filum Terminale Associated with Von Hippel-Lindau Disease: A Case Report
}

\author{
Von Hippel-Lindau Hastalığına Eşlik Eden Filum Terminale \\ Hemanjioblastomu: Bir Olgu Sunumu
}

Bulent TUCER ${ }^{1}$, Mehmet Ali EKICI ${ }^{2}$, Burak KAZANCI ${ }^{2}$, Bulent GUCLU²

${ }^{1}$ Erciyes University, Faculty of Medicine, Department of Neurosurgery, Kayseri, Turkey

${ }^{2}$ Sevket Yilmaz Research and Training Hospital, Department of Neurosurgery, Bursa, Turkey

Corresponding Author: Mehmet Ali EKİCi / E-mail: mehmetali.ekici@gmail.com

\begin{abstract}
We report a 41-year-old man who presented with low back pain, lower extremity paresthesia, urinary retention and constipation. Magnetic resonance imaging showed a vascular intradural-extramedullary lesion at the second lumbar vertebral level. His medical history revealed that he had undergone surgery for a cerebellar hemangioblastoma 5 years ago. The patient underwent a spinal operation and a vascular tumor was removed from filum terminale. Pathologic examination of the tumor revealed a hemangioblastoma. Hemangioblastomas may occur sporadically or in association with von Hippel-Lindau disease. In the second case, they are often multiple and accompanied by cerebellar and brainstem lesions. The hemangioblastomas reported in the conus medullaris or in the extramedullary compartment adjacent to the conus medullaris are rare, tumors of the cauda equina are uncommon, and lesions of the filum terminale are extremely rare. We report a patient with von Hippel-Lindau disease having filum terminale hemangioblastoma and discuss the diagnosis, pathogenesis and treatment of hemangioblastoma.
\end{abstract}

KEYWORDS: Filum terminale, Hemangioblastoma, von Hippel-Lindau disease,Treatment

öz

Bel ağrısı, alt ekstremitelerde parestezisi, idrar yapamama ve konstipasyon şikayeti olan 41 yaşında erkek hasta takdim ediyoruz. Hastada yapılan manyetik rözanans tetkiki ikinci lomber vertebra seviyesinde vasküler intradural-extramedüller lezyon gösterdi. Hastanın medikal hikayesinden 5 sene önce serebellar hemanjioblastom nedeniyle opere edildiği öğrenildi. Hasta spinal bölgesinden opere edildi ve filum terminaleden vasküler tümör çıkarıldı. Tümörün patoloji sonucu hemanjioblastom olarak bildirildi. Hemanjioblastomlar sporadik olarak görülebilir veya Von Hippel-Lindau hastalığına eşlik eder. Von Hippel-Lindau hastalığına eşlik ettiği zaman çoğunlukla multipl olurlar ve serebellar ve beyin sapı lezyonları ile beraber gözükürler. Hemanjioblastomlar konus medullaris ve konus medullarise komşu ekstramedullar alanda nadir olarak gözükürler, kauda ekuinada daha nadirlerdir, filum terminalede ise çok ender gözükürler. Biz filum terminalesinde hemanjioblastom olan ve Von Hippel-Lindau hastalığı olan bir hasta takdim ediyoruz ve hemanjioblastomun teşhisini, patojenezini ve tedavisini tartışıyoruz.

ANAHTAR SÖZCÜKLER: Filum terminale, Hemanjioblastom, von Hippel-Lindau hastalığı, Tedavi

\section{INTRODUCTION}

Spinal cord hemangioblastomas (HBs) account for $1.6-2.1 \%$ of all spinal cord tumors, and may occur sporadically (67-75\%) or as a manifestation of von Hippel-Lindau (VHL) disease $(25-33 \%)(3,4,8,9,12,16)$. Seventy-five percent of spinal HBs are intramedullary, described in all spinal compartments and more commonly reported in the cervical or thoracic location $(9,19,27)$. Extramedullary-intradural HBs may arise from dorsal spinal cord pia or nerve roots $(17,20)$. HBs located in the conus medullaris are rare $(14,16,23,24,30)$, and tumors of the cauda equina $(5,7,11,15)$ are uncommon. Hemangioblastoma of the filum terminale is extremely rare and very few cases were reported in the literature $(1,10,18,26,25,28,29)$. We report a patient with $\mathrm{VHL}$ disease having filum terminale hemangioblastoma and discuss the diagnosis, pathogenesis and treatment of hemangioblastoma.

\section{CASE REPORT}

A 41-year-old male presented with a 3-month history of low back pain and lower extremity paresthesia. He had to strain to pass urine and had constipation. The pain had become progressively worse over the past three months to the point that he could not walk more than half a block without stopping. In his medical history he had undergone surgery for a cerebellar hemangioblastoma 5 years ago (Figure 1 AC). His postoperative period was uneventful after the cranial surgery but five year later he was examined for a neurojenic bladder complaint. His neurological examination showed 
bilateral lower extremity weakness, patellar hyporeflexia and hypoestesia in the medial side of the legs. Magnetic resonance imaging (MRI) revealed a $1.5 \mathrm{~cm}$ diameter intradural tumor at L2 level, which was brilliantly enhancing after gadolinium infusion. The tumor was predominantly isointense on T1weighted images and hypointense on T2-weighted images. Multiple dilated and tortuous vessels exited at the superior pole of the mass (Figure 2A, B). Afterwards, selective spinal angiography was performed, which confirmed the high vascularity of the tumor. The predominant arterial supply to the lesion was from the anterior spinal artery (Figure $2 \mathrm{C}$ ). The patient underwent a spinal operation and L1-L3 laminectomies were performed. After opening of the dura mater, the feeding artery was identified by ultrasonography and coagulated

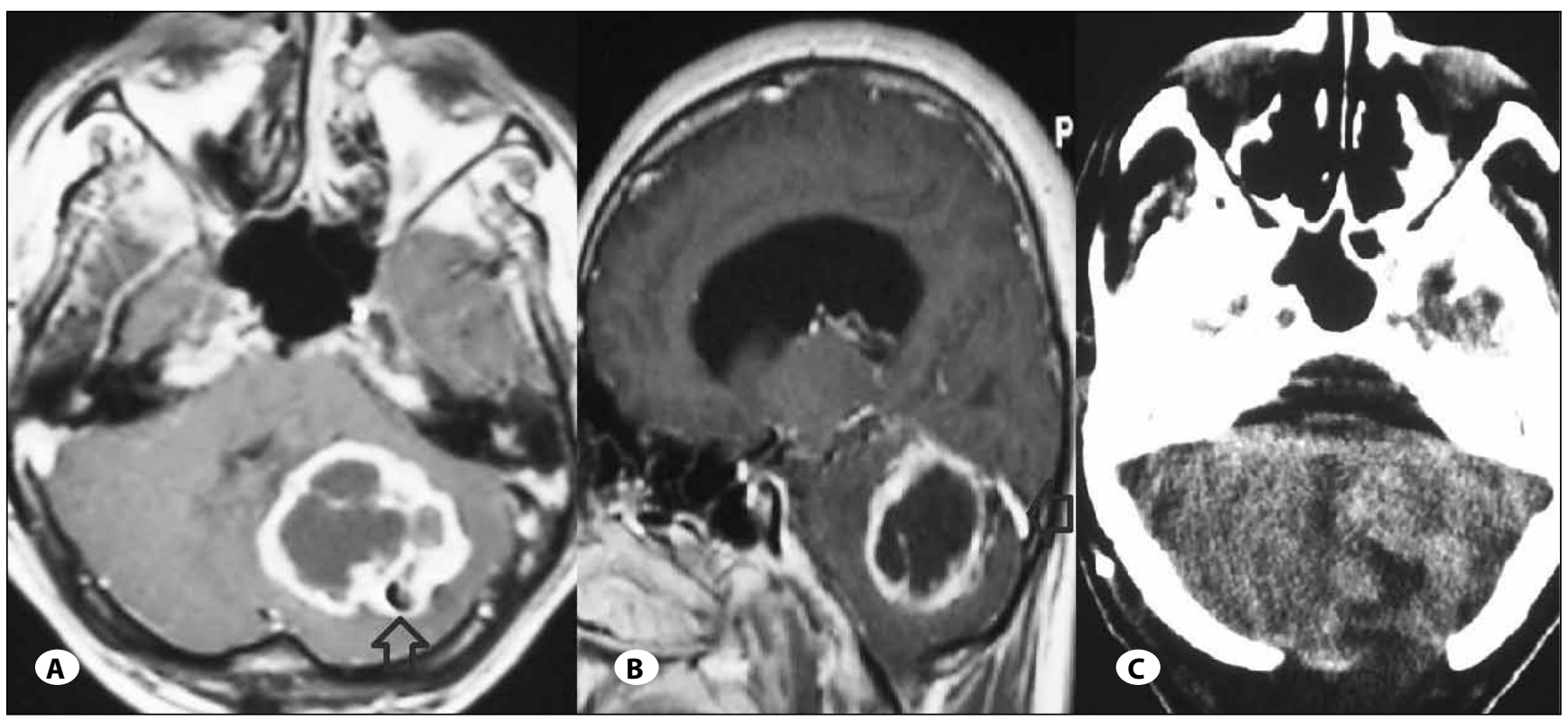

Figure 1: A) Axial CT section with contrast showing left cerebellar hypervascular lesion (arrow). B) Sagittal T1-weighted MRI of the cranium with contrast showing the lesion and arterial feeding (arrow). C) Postoperative axial CT section showing the lesion, which were totally removed.

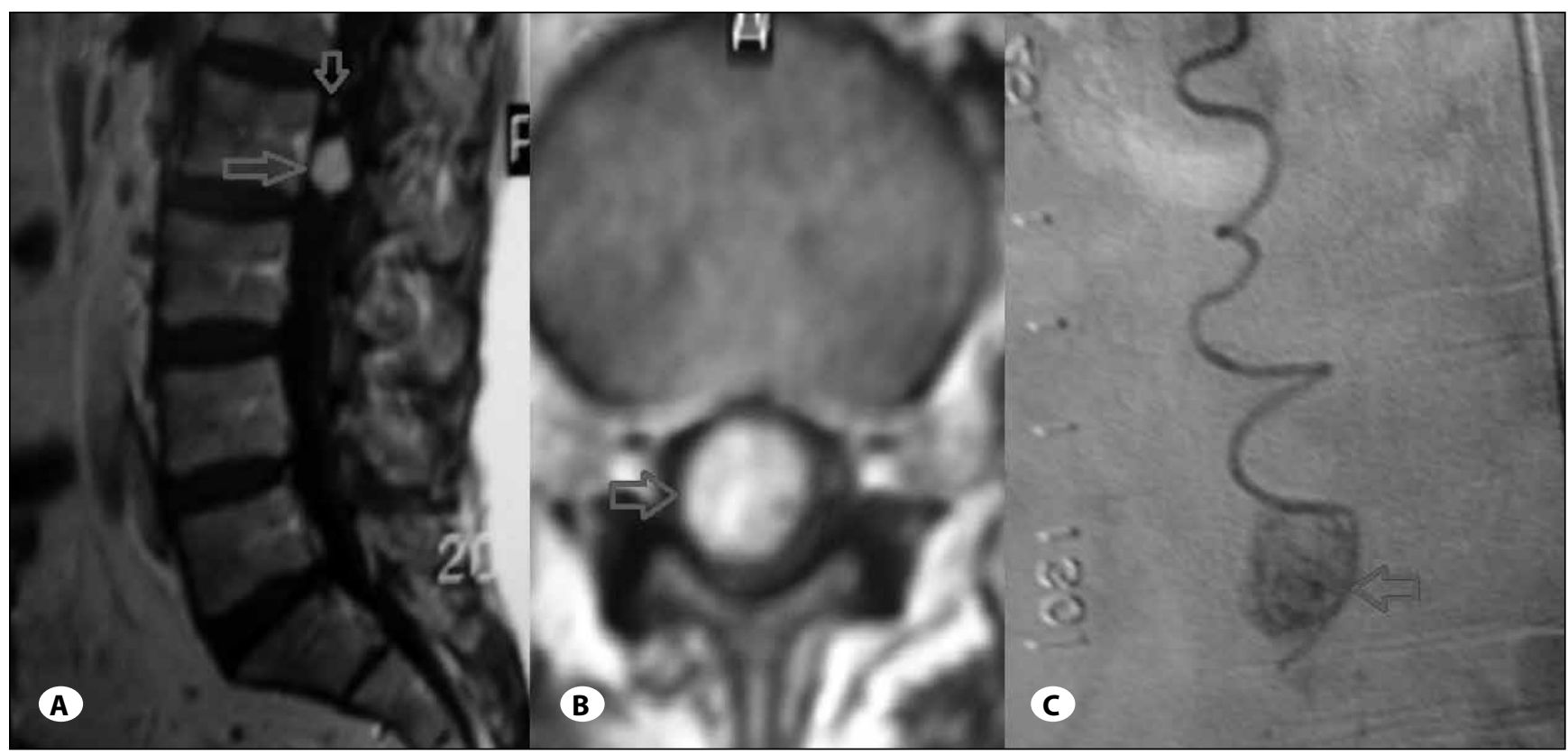

Figure 2: A) Sagittal T1-weighted MRI of the lumbar spine with contrast showing a $1.5 \mathrm{~cm}$ diameter intradural tumor at L2 level, which was brilliantly enhancing after gadolinium infusion (small arrow is showing arterial feeding from superior pole of the mass, large arrow is showing the hypervascular lesion). B) Axial T1-weighted MRI of the lumbar spine with contrast showing an intradural lesion (arrow). C) Selective spinal angiography showing arterial supply (anterior spinal artery) and high vascularity of the tumor (arrow). 


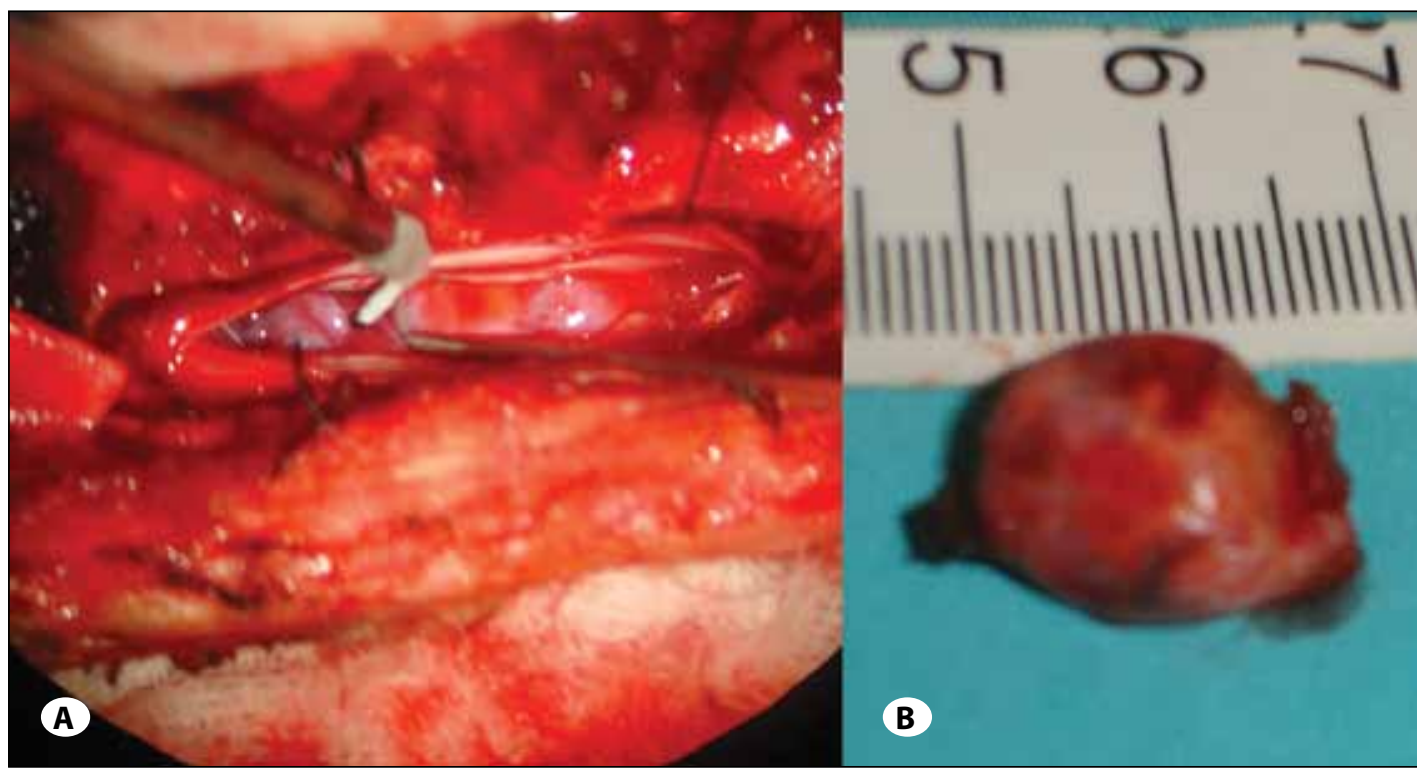

Figure 3: A) Figure showing that feeding artery of the tumor was identified by intraoperative ultrasonography. B) The tumor seen macroscopically after the surgery, and had been totally removed. with bipolar cautery (Figure 3A). Dilated venous channels exiting from superior pole of the tumor were coagulated and divided. The tumor arising from filum terminale was circumferentially dissected, preserving all roots of the cauda equina and excised in an en bloc manner. Macroscopically, the tumor was a reddish-brown, highly vascular lesion (Figure 3B). Histopathology of the tumor showed a highly vascular tumor composed of vascular channels of varying sizes and thickness with intervening stromal polygonal cells with clear to eosinophilic cytoplasm and round to oval hyperchromatic nuclei. Moderate pleomorphism of the cells and clusters of foamy cells were seen. Some vessels were thrombosed and there were foci of hemorrhage. The histological diagnosis was hemangioblastoma. Von Hippel-Lindau clinical screening was positive. The patient's low back pain and lower extremity paresthesia were immediately disappeared after surgery. The weakness in the lower extremities were recovered over 6 months. Bladder and bowel control of the patient were resolved slowly within four months period. Postoperative MRI confirmed complete excision of the mass.

\section{DISCUSSION}

$\mathrm{HBs}$ are low-grade, highly vascular tumors commonly associated with Von Hippel-Lindau Syndrome (VHL) and most commonly occurring in the cerebellum (21). VHL disease is caused by germline mutations of the VHL tumor suppressor gene located on the distal part of the short arm of chromosome 3 (3p25-26). This gene, encoding for a 213amino acid protein, plays a major role in the regulation of vascular endothelial growth factor expression that plays an important role in endothelial cell proliferation $(6,22)$. This finding explains the highly vascular nature of the HBs.

The majority of spinal HBs are intramedullary, and have been described at the cervical and thoracic levels $(9,19,27)$. 21$28 \%$ of spinal $\mathrm{HBs}$ are intradural intradural-extramedullary and $9-13 \%$ of these found within the cauda equina (3). An association with von Hippel-Lindau disease is found in approximately $30 \%$ of all spinal hemangioblastomas. The origin of extramedullary hemangioblastoma is unclear. Extramedullary occurrence of $\mathrm{HBs}$ is more common in patients with Von Hippel Lindau disease; one autopsy report found multiple microscopic spinal root HBs (12). HB of filum terminale is very rarely reported $(1,10,18,25,26,28,29)$. The reported cases were sporadic and not related with VHL. The case we present is part of VHL disease.

Some untreated filum terminale HBs may remain asymptomatic for several years. However as they grow, they may cause compress surrounding neural elements and cause symptoms and by time symptoms aggravate. Most common symptoms of filum terminale $\mathrm{HB}$ are progressive low back and lower extremity pain and weakness. If a filum terminale $\mathrm{HB}$ reaches a certain volume it may also cause cauda equina syndrome.

A spinal HB can be diagnosed accurately pre-operatively using CT and MRI scans alone. Spinal angiography provides information about feeding arteries (mostly anterior spinal artery) of the lesion and venous drainage systems for preoperative strategy planning $(2,13)$. Preoperative embolization is effective in the reduction of intraoperative bleeding and facilitates tumor resection, however it is generally not necessary. The risk of embolization should also be compared with the surgical risk in large and high vascular lesions treated surgically without preoperative devascularization.

Treatment of $H B$ is surgical excision that is possible with low morbidity and results in excellent long-term functional outcome. Circumferential dissection and en bloc removal is the surgical technique for surgical resection. Intra-tumor debulking may cause profuse bleeding. Incomplete resection has been associated with a high rate of recurrence. 


\section{CONCLUSION}

Hemangioblastomas of the filum terminale are extremely rare and reported cases are sporadic and not related with von Hippel-Lindau disease. We report a patient with von HippelLindau disease having filum terminale hemangioblastoma and discuss diagnosis, pathogenesis and treatment of hemangioblastoma.

\section{REFERENCES}

1. Arbelaez A, Castillo M, Armao D: Hemangioblastoma of the filum terminale: MR imaging. AJR Am J Roentgenol 173: 857858, 1999

2. Biondi A, Ricciardi GK, Faillot T, Capelle L, Van Effenterre R, Chiras J: Hemangioblastomas of the lower spinal region: Report of four cases with preoperative embolization and review of the literature. AJNR 26: 936-945, 2005

3. Browne TR, Adams RD, Roberson GH: Hemangioblastoma of the spinal cord: Review and report of five cases. Arch Neurol 33: 435-441, 1976

4. Cawthon DF, Cacayorin ED, Modesti LM, Lin L, King RB: Spinal vascular tumors: Dilemmas in diagnosis and management. Neurosurgery 16: 625-629, 1985

5. Chazono M, Shiba R, Funasaki H, Soshi S, Hattori A, Fujii K: Hemangioblastoma of the L-5 nerve root: Case illustration. J Neurosurg 90: 160, 1999

6. Couch V, Lindor NM, Karnes PS, Michels VV: von HippelLindau disease. Mayo Clin Proc 75:265-272, 2000

7. Da Costa LB Jr, de Andrade A, Braga BP, Ribeiro CA: Cauda equina hemangioblastoma: Case report. Arq Neuropsiquiatr 61: 456-458, 2003

8. Di Chiro G, Doppman JL: Differential angiographic features of hemangioblastomas and arteriovenous malformations of the spinal cord. Radiology 93: 25-30, 1969

9. Emery E, Hurth M, Lacroix-Jousselin C, David P, Richard S: Intraspinal hemangioblastoma. Apropos of a recent series of 20 cases. Neurochirurgie 40(3): 165-173, 1994

10. Farneti M, Ferracini R, Migliore A, Trapella G, Veronesi V: Isolated hemangioblastoma of the filum terminale. Case report. J Neurosurg Sci 45: 58-62, 2001

11. Giannini C, Scheithauer BW, Hellbusch LC, Rasmussen AG, Fox MW, McCormickSR, et al: Peripheral nerve hemangioblastoma. Mod Pathol 11: 999-1004, 1998

12. Ismail SM, Cole G: Von Hippel-Lindau syndrome with microscopic hemangioblastomas of the spinal nerve roots. J Neurosurg 60:1279-1281, 1984

13. Kern M, Naeini R, Lehmann TN, Benndorf G: Imaging of a thoracic spinal nerve haemangioblastoma by threedimensional digital angiography. Journal of Clinical Neuroscience 13:929-932, 2006

14. Lee DK, Choe WJ, Chung CK, Kim HJ: Spinal cord hemangioblastoma: Surgical strategy and clinical outcome. J Neurooncol 61: 27-34, 2003
15. Lonser RR, Wait SD, Butman JA, Vortmeyer AO, Walther MM, Governale LS, et al: Surgical management of lumbosacral nerve root hemangioblastomas in von Hippel-Lindau syndrome. J Neurosurg 99: 64-69, 2003

16. Lunardi P, Cervoni L, Maleci A, Fortuna A: Isolated haemangioblastoma of spinal cord: Report of 18 cases and a review of the literature. Acta Neurochir (Wien) 122: 236-239, 1993

17. McEvoy AW, Benjamin E, Powell MP: Haemangioblastoma of a cervical sensory nerve root in Von Hippel-Lindau syndrome. Eur Spine J 9: 434-436, 2000

18. Nadkarni TD, Menon RK, Desai KI, Goel A: Hemangioblastoma of filum terminale: Case report. Journal of Clinical Neuroscience 13:285-291, 2006

19. Osborn AG: Tumor cysts and tumor like lesions of the spine and spinal cord. In: Osborn AG, (ed). Diagnostic Neuroradiology. Saint Louis: Mosby, 1994:876 -917

20. Raghavan R, Krumerman J, Rushing EJ, White CL 3rd, Chason DP, Watson ML, et al: Recurrent (nonfamilial) hemangioblastomas involving spinal nerve roots: Case report. Neurosurgery 47: 1443-1448, 2000

21. Richard S, Campello C, Taillandier L, Parker F, Resche F: Haemangioblastoma of the central nervous system in von Hippel-Lindau disease. J Intern Med 243: 547-553, 1998

22. Richard S, Martin S, David P, Decq P:Von Hippel-Lindau disease and central nervous system hemangioblastoma: Progress in genetics and clinical management. Neurochirurgie 44: 258-266, 1998

23. Roonprapunt C, Silvera VM, Setton A, Freed D, Epstein FJ, Jallo Gl: Surgical management of isolated hemangioblastomas of the spinal cord. Neurosurgery 49: 321-328, 2001

24. Spetzger U, Bertalanffy H, Huffmann B, Mayfrank L, Reul J, Gilsbach JM: Hemangioblastomas of the spinal cord and the brainstem: Diagnostic and therapeutic features. Neurosurg Rev 19: 147-151, 1996

25. Sloof JL, Kernohan JW, MacCarty CS: Primary Intramedullary Tumors of the Spinal Cord and Filum Terminale. Philadelphia: WB Saunders Co; 1964

26. Tibbs RE Jr, Harkey HL, Raila FA: Hemangioblastoma of the filum terminale: Case report. Neurosurgery 44: 221-223, 1999

27. Wanebo JE, Lonser RR, Glenn GM, Oldfield EH: The natural history of hemangioblastomas of the central nervous system in patients with von Hippel-Lindau disease. J Neurosurg 98: 82-94, 2003

28. Wolbers JG, Ponssen $\mathrm{H}$, Kamphorst W: Hemangioblastoma of the cauda equina. Clin Neurol Neurosurg 87: 55-59, 1985

29. Wyburn-Mason R: The Vascular Abnormalities and Tumors of the Spinal Cord and Its Membranes. London: Henry Kimpton, 1943:1-196

30. Yasargil MG, Antic J, Laciga R, de Preux J, Fideler RW, Boone SC: The microsurgical removal of intramedullary spinal hemangioblastomas. Report of twelve cases and a review of the literature. Surg Neurol 3: 141-148, 1976 